\title{
On the Beneficial Role of Silicon to Organisms: A Case Study on the Importance of Silicon Chemistry to Metal Accumulation in Yeast
}

\author{
H. J. Brasser • G. C. Krijger • H. T. Wolterbeek
}

Received: 8 April 2008 / Accepted: 18 April 2008 /

Published online: 13 May 2008

(C) Humana Press Inc. 2008

\begin{abstract}
Silicon is involved in numerous important structural and functional roles in a wide range of organisms, including diatoms, plants, and humans, but clear mechanisms have been discovered only in diatoms and sponges. Silicate availability influences metal concentrations within various cell- and tissue-types, but a mechanism has not been discovered so far. In an earlier study on Baker's yeast Saccharomyces cerevisiae it was proposed that a chemical mechanism, rather than a biological one, is important. In the present study, the interaction of silicon with Baker's yeast is further investigated by studying the influence of zinc and magnesium on Si accumulation both at a low and a high silicate concentration in the medium. Si accumulation fitted well with Freundlich adsorption and $\mathrm{Si}$ release followed depolymerization kinetics, indicating that silicate adsorbs to the surface of the cell rather than being transported over the cell membrane. Subsequently, adsorbed silicate interacts with metal ions and, therefore, alters the cell's affinity for these ions. Since several metals are nutritional, these $\mathrm{Si}$ interactions can significantly change the growth and viability of organisms. In conclusion, the results show that chemistry is important in Si and metal accumulation in Baker's yeast, and suggest that similar mechanisms should be studied in detail in other organisms to unravel essential roles of Si.
\end{abstract}

Keywords Silicon $\cdot$ Baker's yeast $\cdot$ Silicate chemistry $\cdot$ Adsorption $\cdot$ Metals

\section{Introduction}

Silicon $(\mathrm{Si})$ is the second most abundant element $(25.7 \% \mathrm{w} / \mathrm{w})$ in the earth's crust, being exceeded only by oxygen (49.2\%) [1]. In natural waters, silicon is present as silicic acid, in concentration ranging from 0.07 to $0.2 \mathrm{mmol} / 1$ [2-5]. Silicic acid is undissociated at neutral

H. J. Brasser $(\bowtie) \cdot$ G. C. Krijger $•$ H. T. Wolterbeek

Faculty of Applied Sciences, Department of Radiation, Radionuclides \& Reactors,

Section Radiation and Isotopes for Health, Delft University of Technology, Mekelweg 15, 2629 JB Delft, The Netherlands

e-mail: H.J.Brasser@tudelft.nl 
$\mathrm{pH}$. At low concentrations $(<2 \mathrm{mmol} / \mathrm{l})$, it has the form of orthosilicic acid $\left[\mathrm{Si}(\mathrm{OH})_{4}\right]$, but above this concentration polymerization is initiated, forming orthosilicate oligomers. Polymeric silicate depolymerizes to orthosilicic acid when diluted to concentrations below $2 \mathrm{mmol} / \mathrm{l}[6,7]$.

Silicon is omnipresent in the ecosystem, and during the evolution life had to cope with its presence. It may have played a significant role in the origin of life [8], and it is considered to be essential or beneficial to various organisms, including humans, although only a few functions of silicon have been unraveled so far. In both plants and animals, silicon participates in essential structural and functional roles. For example, in plants, silicon-based compounds are involved in providing mechanical strength and protection against drought, pathogens and metal toxicity [9-11]. In higher animals, silicon compounds influence the production of bone and cartilage, lipid metabolism and DNA synthesis, and affect several enzymatic activities. Furthermore, both in plants and higher animals, silicon can influence the concentration of essential metals within tissues [12-16]. Despite these important roles for silicon only in the diatoms and sponges the underlying mechanisms are well understood $[17,18]$.

Very little is known of biological silicate interactions in higher animals, and despite many efforts a biological process or silicate binding site has not been found so far [12-16]. This could be due to the focus on biological processes (e.g., in enzymes or binding sites) so far, while the indirect role of silicon via (physical) chemical processes could be far more important [19]. Namely, silicate molecules in solution show a rich chemistry, including adsorption, (de)polymerization reactions and complex formation with metal ions [7, 2024]. Probably silicate could play a role in organisms by its chemical interactions with metal ions. Silicate-metal complexes could influence the availability of metals that are important for the organism (e.g., as an enzymatic cofactor). The effects on several biological processes could then be ascribed to the availability of important metal ions.

To investigate this hypothesis, the single cell organism Baker's yeast was used. Yeast is the most common model for eukaryotic cells, it is easy to handle and culture, and it lacks the many additional complicating experimental parameters of a higher organism [25]. The study on Baker's yeast revealed that silicate affects metal concentrations and metal uptake rates in the cell, and that under certain conditions, the growth rate was affected. It was proposed that silicate adsorbed on the cell wall and influenced the metal availability for the cell by the formation of silicate-metal complexes [26].

In the present paper, this hypothesis is further investigated. We focus on this possibly crucial indirect (physical) chemical role of silicon in living organisms rather than a biological one. The accumulation of silicate in yeast cells is investigated, and it is determined whether this process can be described by a biological or a (physical) chemical process. Finally, the interaction of silicate with metal ions is studied. Radiotracer techniques are used to study the accumulation of silicate in yeast cells.

\section{Materials and Methods}

\section{Chemicals and Labware}

All chemicals were at least of analytical grade and obtained from BDH (Amsterdam, The Netherlands) or Aldrich (Zwijndrecht, The Netherlands). All solutions were prepared in ultrapure water (18.2 M $/ / \mathrm{cm}$, Millipore Milli-Q, Billerica, MA, USA).

Precautions were taken to avoid silicate contamination from dust, chemicals and water: (1) all used labware was made of polycarbonate or polypropylene, (2) labware was rinsed 
with $1 \mathrm{~mol} / \mathrm{l} \mathrm{HCl}$, then rinsed with demineralized water and finally washed with ultrapure water, and (3) a laminar flow cabinet was used to prevent dust contamination and to ensure sterile conditions during sampling and inoculation. Despite all precautions, it was not possible to obtain a silicate free cell culture. No-Si-added media contain $1 \mu \mathrm{mol} / 1$ silicate.

${ }^{31} \mathrm{Si}$-silicate $\left(t_{1 / 2} 2.62 \mathrm{~h}, \beta^{-} 1.49 \mathrm{MeV}\right)$ was produced in the nuclear reactor of the Reactor Institute Delft, University of Technology Delft, The Netherlands. No-carrier-added ${ }^{31} \mathrm{Si}-$ silicate solution (specific activity $4.8 \mathrm{TBq} / \mathrm{g}$ ) was prepared by purification using a chemical precipitation reaction with barium carbonate as described earlier [27].

\section{Organism and Culture Procedures}

The yeast strain Saccharomyces cerevisiae CEN.PK 113-7D, wild type (kindly provided by the Kluyver laboratory for Biotechnology, University of Technology Delft, The Netherlands), was cultured in standard mineral medium ( $\mathrm{pH}$ 6.5) [28], containing the following compounds per liter: $\left(\mathrm{NH}_{4}\right)_{2} \mathrm{SO}_{4}, 5 \mathrm{~g} ; \mathrm{KH}_{2} \mathrm{PO}_{4}, 3 \mathrm{~g} ; \mathrm{MgSO}_{4} .7 \mathrm{H}_{2} \mathrm{O}, 0.5 \mathrm{~g}$; EDTA, $15 \mathrm{mg} ; \mathrm{ZnSO}_{4} .7 \mathrm{H}_{2} \mathrm{O}, 4.5 \mathrm{mg} ; \mathrm{CoCl}_{2} \cdot 6 \mathrm{H}_{2} \mathrm{O}, 0.3 \mathrm{mg} ; \mathrm{MnCl}_{2} .4 \mathrm{H}_{2} \mathrm{O}, 1 \mathrm{mg}$; $\mathrm{CuSO}_{4} .5 \mathrm{H}_{2} \mathrm{O}, 0.3 \mathrm{mg} ; \mathrm{CaCl}_{2} .2 \mathrm{H}_{2} \mathrm{O}, 4.5 \mathrm{mg} ; \mathrm{FeSO}_{4} .7 \mathrm{H}_{2} \mathrm{O}, 3 \mathrm{mg} ; \mathrm{NaMoO}_{4} .2 \mathrm{H}_{2} \mathrm{O}$, $0.4 \mathrm{mg} ; \mathrm{H}_{3} \mathrm{BO}_{4}, 1 \mathrm{mg}$; and $\mathrm{KI}, 0.1 \mathrm{mg}$. Final vitamin concentrations per liter were as follows: biotin, $0.05 \mathrm{mg}$; calcium pantothenate, $1 \mathrm{mg}$; nicotinic acid, $1 \mathrm{mg}$; inositol, $25 \mathrm{mg}$; thiamine $\mathrm{HCl}, 1 \mathrm{mg}$; pyridoxine $\mathrm{HCl}, 1 \mathrm{mg}$; and para-aminobenzoic acid, $0.2 \mathrm{mg}$. The carbon source consisted of $10 \mathrm{~g} / \mathrm{l}$ glucose. Culture procedures and sampling were carried out under sterile conditions in a laminar flow cabinet. The organism was grown aerobically, in batch culture within $500 \mathrm{ml}$ Erlenmeyer flasks containing $100 \mathrm{ml}$ standard medium, in an incubator (New Brunswick Scientific, Edison, NJ, USA), maintained at $180-200 \mathrm{rpm}$ and $30^{\circ} \mathrm{C}$. The biomass of the culture was determined from the optical density at $660 \mathrm{~nm}\left(\mathrm{OD}_{660}\right)$ of the culture $\left(\mathrm{OD}_{660}\right.$ unit corresponded with $0.39 \mathrm{~g} / 1$ dry weight).

Silicate was added from a potassium silicate $\left(\mathrm{K}_{2} \mathrm{SiO}_{3}\right)$ stock, $0.1 \mathrm{~mol} / \mathrm{l}$, which was freshly prepared. High $\mathrm{Zn}^{2+}$ concentrations in the growth medium were obtained by addition of $\mathrm{Zn}^{2+}$ from a $10 \mathrm{mmol} / 1 \mathrm{ZnCl}$ stock solution. Low $\mathrm{Mg}^{2+}$ cultures were obtained by inoculation of the experimental flasks (containing $80 \mathrm{ml} \mathrm{Mg}{ }^{2+}$-deficient medium) with $20 \mathrm{ml}$ from a normal preculture. Cultures low in $\mathrm{Zn}^{2+}$ were obtained in two steps by

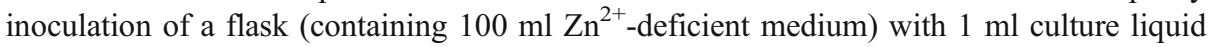
from a normal preculture. After $24 \mathrm{~h}$ of growth, the experimental flasks (containing $80 \mathrm{ml}$ Zn-deficient medium) were inoculated with $20 \mathrm{ml}$ from this culture.

Some experiments were carried out on dead cells, which were obtained by $\gamma$-irradiation of a culture with a $10 \mathrm{kGy}$ dose $\left({ }^{60} \mathrm{Co}\right.$ source, Gammacell ${ }^{\circledR} 220$ Excel, MDS Nordion). Viability of the cells was examined by determination of the growth rate and by methylene blue staining.

\section{Analyses}

Inductively coupled plasma optical emission spectrometry (ICP-OES, Perkin Elmer OES Optima 4300DV, Boston, USA) was used to determine Si, Co, and $\mathrm{Zn}$ concentrations in the culture liquid. For calibration, Merck CertiPUR standard solutions 1703 (Amsterdam, The Netherlands) were used. Culture liquid samples were taken directly after inoculation, and yeast cells were removed, by centrifugation $(600 \times \mathrm{g}, 10 \mathrm{~min})$, prior to analysis.

The activity of ${ }^{31} \mathrm{Si}$ was measured on a LKB liquid scintillation counter ( $\beta^{-}$radiation) using Ultima Gold XR liquid scintillation counting cocktail. Filters containing radioactive 
samples were dissolved in $10 \mathrm{ml}$ liquid scintillation counting (LSC) cocktail within a counting vial prior to analysis. The volume of liquid samples was adjusted to $5 \mathrm{ml}$ with demineralized water and mixed with $15 \mathrm{ml}$ LSC counting cocktail prior to analysis.

\section{${ }^{31} \mathrm{Si}$ Accumulation in Yeast Cells}

No carrier-added ${ }^{31} \mathrm{Si}$ tracer solution $(0.1-0.5 \mathrm{ml}, 50-250 \mathrm{kBq}, 4.8 \mathrm{TBq} / \mathrm{g})$ was added to $80 \mathrm{ml}$ standard medium. The solution was mixed well and allowed to equilibrate for at least $15 \mathrm{~min}$ prior to inoculation. The flasks were inoculated with $20 \mathrm{ml}$ from a standard no-Si added yeast preculture $\left(\mathrm{OD}_{660} 2-3\right)$. Culture conditions were chosen as such that the $\mathrm{OD}_{660}$ did not change during the experiment. To determine the ${ }^{31} \mathrm{Si}$ tracer accumulation, $10 \mathrm{ml}$ samples were taken from the culture. Samples were taken after $120 \mathrm{~min}$ of incubation, unless stated otherwise. The samples were filtered over a $0.45 \mu \mathrm{m}$ membrane filter and washed with $2.5 \mathrm{ml}$ standard medium containing $5 \mathrm{mmol} / 1 \mathrm{Si}$. The filters and a 1-ml sample of the culture suspension were kept for determination of amounts of radioactivity. These amounts of radioactivity were related to $\mathrm{OD}_{660}$ and silicate concentration in the samples to calculate the silicate accumulation in mol/g DW. A correction was applied for ${ }^{31} \mathrm{Si}$ adsorption on the filter.

\section{Determination of ${ }^{31} \mathrm{Si}$ Release}

Yeast cells were cultured in medium containing $10 \mathrm{mmol} / 1$ silicate and ${ }^{31} \mathrm{Si}(1 \mathrm{MBq})$ as described above. After $4 \mathrm{~h}$ the biomass of the culture was harvested by centrifugation (20 min, $600 \times g$ ), washed once in medium containing $10 \mathrm{mmol} / 1$ silicate. At $t=0$, the cells were resuspended in $50 \mathrm{ml}$ standard no-Si added medium (not containing ${ }^{31} \mathrm{Si}$ ). At regular intervals, a $1.5-\mathrm{ml}$ sample of the culture was put in an Eppendorf vial and centrifuged $(1 \mathrm{~min}, 1800 \times g)$. The supernatant $(1 \mathrm{ml})$ and a sample of the suspension $(1 \mathrm{ml})$ were kept for activity determination. The activity was related to the silicate concentration in the in the original culture and to $\mathrm{OD}_{660}$ of the suspension to calculate the silicate concentration in the biomass $\left(C_{\text {cell }}\right.$ in mol/l) and in the release medium $\left(C_{\text {med }}\right.$ in mol/l). The decrease of the silicate concentration in the biomass $C_{\text {cell }}$ in time was fitted to pseudo second order depolymerization kinetics (see below).

\section{Determination of the Freundlich Parameters $1 / n$ and $K$}

The adsorption of a compound on a surface can be described by a Freundlich isotherm [29]. The process is defined by two parameters: $1 / n$ as the order of the adsorption process, and $K_{\text {ads }}$ as the affinity of the adsorbed compound for that specific surface (defined as the adsorption in $1 \mathrm{~mol} / \mathrm{l}$ solute).

$$
\frac{x}{m}=K_{a d s} * C_{m e d}^{\frac{1}{n}}
$$

with $x$ as the amount of solute adsorbed by mass $m$ of a solid (in this case the amount of silicate per mass of dry weight of yeast cells), $C_{\text {med }}$ as the solute concentration (in this case the silicate concentration in the medium), $1 / n$ as the order of the adsorption reaction, and $K_{\text {ads }}$ as the affinity (adsorption at $1 \mathrm{~mol} / \mathrm{l}$ solute). The equation can be rewritten as:

$$
\log \frac{x}{m}=\log K_{\text {ads }}+\frac{1}{n} * \log C_{\text {med }}
$$


Plotting log adsorption against log concentration yields a straight line with a slope $1 / n$ and an abscissa $\log K_{\text {ads. }}$.

Determination of the Depolymerization Rate Constant

The depolymerization of polysilicate is described as earlier $[22,24]$ and is determined by the depolymerization rate constant $K_{d, 0}[\mathrm{in} 1 /(\mathrm{mol} \cdot \mathrm{s})] . K_{d, 0}$ is dependant of the $\mathrm{pH}$ and the temperature:

$$
K_{d, 0}=5.614 * 10^{-10} * p H^{11.61} * \exp \left(-\frac{11526}{T}+39.32\right)
$$

with temperature $T$ in $K . K_{d, 0}$ is influenced by the presence of ions in the solution. The rate constant corrected for ions in the solution $K_{d}$ is calculated following:

$$
K_{d}=K_{d, 0} * \Pi\left(\exp \left(A *\left(\exp \left(a_{i} * B\right)-\exp \left(a_{i} * C\right)\right)\right)\right)
$$

with $a_{i}$ as the activity of ion $i$. The constants $A, B$ and $C$ are summarized in Dietzel [22] for different ions. At $\mathrm{pH} 6.5,30^{\circ} \mathrm{C}$ and standard medium composition the $K_{d}$ value is $25.2 \mathrm{l} /$ (mol-min) $[0.421 \mathrm{l} /(\mathrm{mol} \cdot \mathrm{s})]$. The initial monosilicate and polysilicate concentration $\left(C_{\mathrm{med}, i}\right.$ and $\left.C_{\mathrm{cell}, i}\right)$ in the solution also influence the depolymerization rate constant. Two correction factors $\alpha_{\mathrm{M}}$ and $\alpha_{\mathrm{P}}$ have to be introduced to obtain the rate constant $K$ that is actually measured in the solution:

$$
K=K_{d} * \alpha_{M} * \alpha_{P}
$$

with $\alpha_{\mathrm{M}}$ and $\alpha_{\mathrm{P}}$ :

$$
\begin{gathered}
\alpha_{M}=0.8053 * \frac{C_{\mathrm{med}, i}}{C_{\mathrm{cell}, i}}+1 \\
\alpha_{P}=\exp \left(2.708-0.894 * \ln \left(C_{\text {cell }, i}\right)\right)
\end{gathered}
$$

with $C_{\text {cell, } i}$ in $\mathrm{mg} \mathrm{SiO}_{2} / 1$. The polysilicate depolymerization reaction follows pseudo second order kinetics and is expressed as:

$$
\frac{C_{\mathrm{tot}}}{C_{\mathrm{cell}}}=K * t * C_{\mathrm{tot}}+\frac{C_{\mathrm{tot}}}{C_{\mathrm{cell}, i}}
$$

with $t$ as time $(\mathrm{min}), C_{\text {tot }}$ as the total silicate $(\mathrm{mol} / \mathrm{l} ;=$ total silicate present in cell suspension), $C_{\text {cell }}$ as the polysilicate concentration (mol/l; as polysilicate on the cell wall), and $K$ as the above described rate constant [1/( $\mathrm{mol} \cdot \mathrm{min})]$. Rearranging formula (2) (division by $C_{\text {tot }}$ ) yields:

$$
\frac{1}{C_{\mathrm{cell}}}=K * t+\frac{1}{C_{\mathrm{cell}, i}}
$$

The decrease of $C_{\text {cell }}$ in time is fitted in formula (3) using linear regression resulting in a $K$ value (slope) and $1 / C_{\text {cell,i }}$ value (abscissa). The obtained $K$ value is valid for the initial mono- and polysilicate concentrations for that particulate experiment. To compare the obtained $K$ value with the $K_{d}$ value for the given $\mathrm{pH}$, temperature and medium composition [25.2 $\mathrm{l} /(\mathrm{mol} \cdot \mathrm{min})]$ the obtained $K$ value has to be divided by $\alpha_{\mathrm{M}}$ and $\alpha_{\mathrm{P}}$ to yield the experimental value for $K_{d}$. 


\section{Results}

Determination of Experimental Conditions and Non-biological Components in Silicate-cell Interaction

To determine whether silicate accumulation in yeast cells (i.e., in the cell or on the cell wall) takes place, and to choose the experimental conditions for the other experiments, the silicate accumulation is followed in time at two silicate concentrations: $1 \mu \mathrm{mol} / 1$ (i.e., no-Si added, no silicate polymerization) and $5 \mathrm{mmol} / 1$ (high concentration, silicate polymerization; Fig. 1). Silicate accumulation by yeast cells is observed in $1 \mu \mathrm{mol} / \mathrm{l}$ as well as in $5 \mathrm{mmol} / 1$ silicate. In $1 \mu \mathrm{mol} / 1$ the silicate accumulation is linear in time over the time course studied, whereas in $5 \mathrm{mmol} / \mathrm{l} \mathrm{Si}$ the silicate accumulation has the form of a saturation curve. Possibly the accumulation in $1 \mu \mathrm{mol} / 1$ silicate also has the form of a saturation curve at longer time intervals, but due to the decay rate of the ${ }^{31} \mathrm{Si}$ tracer it was not possible to investigate this any further. At short incubation times $(<30 \mathrm{~min})$, the errors in the measurements are large, so longer incubation times are preferred. On the other hand, it is not possible to take the incubation time too long because of the decay rate of the ${ }^{31} \mathrm{Si}$ tracer. Based on these results,

Fig. 1 Silicate accumulation (in mol per g dry weight) in time by Baker's yeast (Saccharomyces cerevisiae). The cells were cultured in a $1 \mu \mathrm{mol} / 1$ silicate, and in b $5 \mathrm{mmol} / \mathrm{l}$ silicate, and the silicate accumulation in the cells was followed in time using a

${ }^{31} \mathrm{Si}$-silicate tracer. Note that the $y$-axis in a runs from $-5 \cdot 10^{-11}$ to $3 \cdot 10^{-10}$. All datapoints are averages $(n \geq 3, \pm \mathrm{SD})$

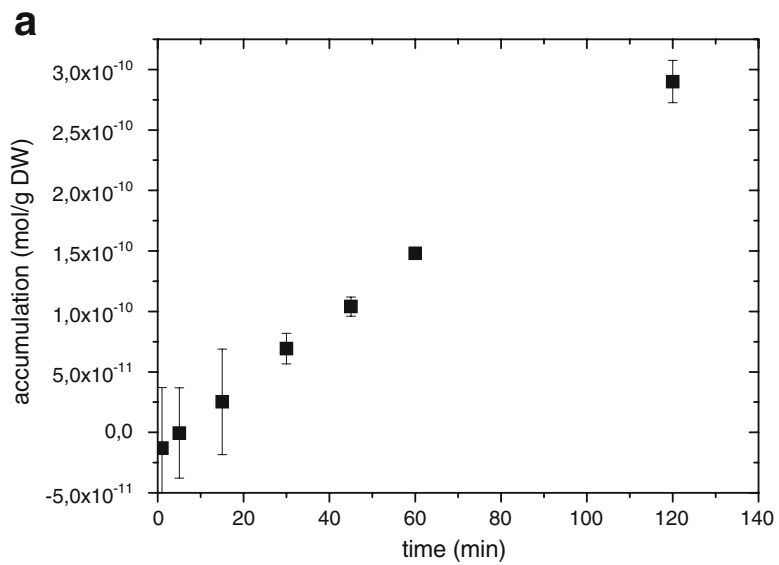

b

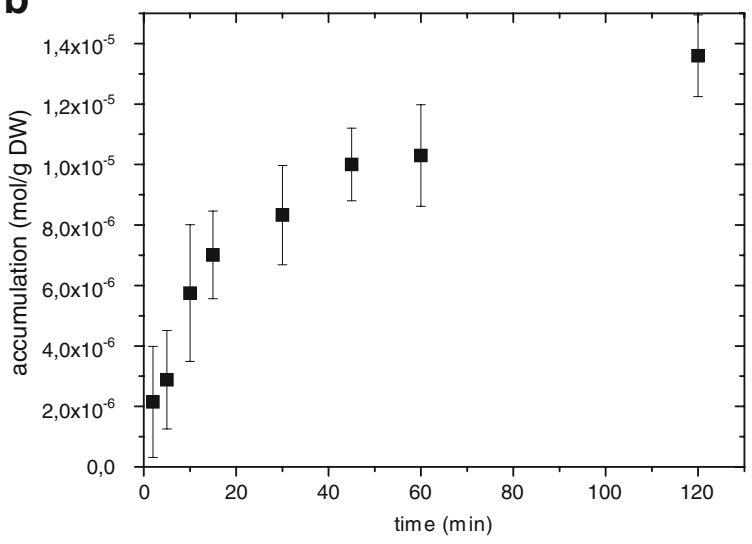


120 min incubation is chosen for all further experiments. At this time, the accumulation reaches its saturation point in $5 \mathrm{mmol} / \mathrm{l}$.

To investigate whether biology plays a role, the Si accumulation is determined in dead cells and at $0^{\circ} \mathrm{C}$ (living cells). Under these conditions, all biological processes come to a complete standstill, so any observed accumulation can be ascribed to a non-biological process. Dead cells were obtained by $\gamma$-irradiation of a culture with a $10 \mathrm{kGy}$ dose followed by microscopic examination (see "Materials and Methods"). The sufficient dose was determined by irradiation of a culture followed by the determination of the growth rate (Fig. 2) and by microscopic examination (methylene blue staining). A 10-kGy dose completely stopped the growth while microscopic examination revealed that the dead cells were still intact. The size of the irradiated cells (10 kGy) was increased about 1.5 times in diameter.

The accumulation in dead cells $\left(30^{\circ} \mathrm{C}\right)$ and in living cells $\left(0^{\circ} \mathrm{C}\right)$ is investigated in $1 \mu \mathrm{mol} / 1$ silicate and compared to accumulation in living cells at $30^{\circ} \mathrm{C}$ (standard medium and conditions), $120 \mathrm{~min}$ incubation. Because dead cells showed an increase in diameter, the silicate accumulation in dead cells can also provide some information on the influence of the cell size on the process. The silicate concentration of $1 \mu \mathrm{mol} / 1$ ensures that no silicate polymerization takes place. The experiment is repeated in $5 \mathrm{mmol} / \mathrm{l}$ silicate to investigate for possible additional effects of silicate polymerization in the medium (Fig. 3).

Silicate accumulation is observed in dead cells and at $0^{\circ} \mathrm{C}$. Lowering the temperature to $0^{\circ} \mathrm{C}$ does not influence silicate accumulation in $1 \mu \mathrm{mol} / 1$ silicate, which is an indication that the silicate interaction with the cell is likely of non-biological origin. In $5 \mathrm{mmol} / \mathrm{l}$ silicate, the silicate accumulation is reduced with $73 \%$. This result may indicate that both biological accumulation and silicate chemistry should also be taken into account at this silicate concentration.

The accumulation in dead cells is increased compared to normal living cells $(147 \%$ in $1 \mu \mathrm{mol} / 1 \mathrm{Si}$, and $48 \%$ in $5 \mathrm{mmol} / \mathrm{l} \mathrm{Si}$ ). It can be calculated that the increase of the silicate accumulation in dead cells corresponds reasonably well with the increase of the cell surface area (increase of cell diameter by a factor 1.2-1.7). Although based on these results, the existence of a biological process cannot be ruled out the existence of a chemical interaction of silicate with the cell becomes more likely. This is further investigated in the next experiment.

Fig. 2 Influence of the $\gamma$-dose on the growth rate of Baker's yeast. A yeast culture was irradiated with different $\gamma$-radiation doses from a ${ }^{60} \mathrm{Co}$ source. Samples were taken to determine the growth rate and the viability of the irradiated cells

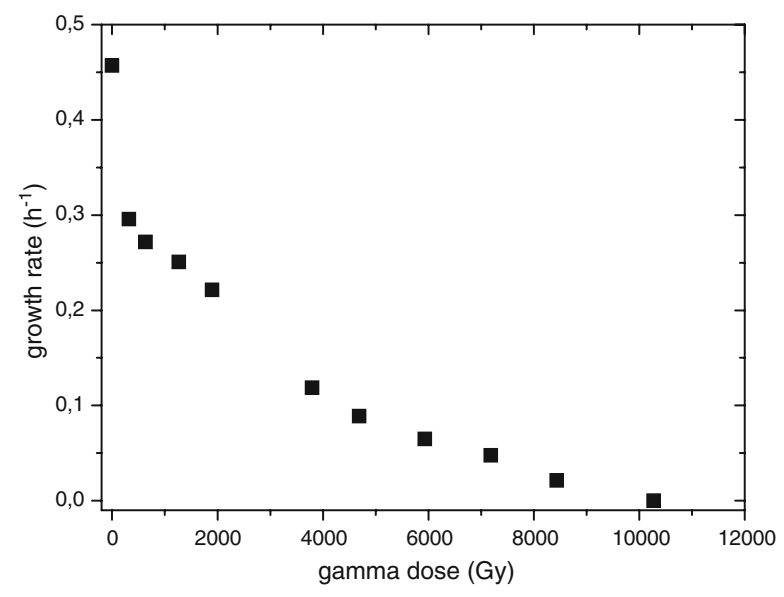


Fig. 3 Silicate accumulation in Baker's yeast cultured in a $1 \mu \mathrm{mol} / 1$ silicate, and in b $5 \mathrm{mmol} / 1$ silicate. Yeast is cultured for $2 \mathrm{~h}$ at $30^{\circ} \mathrm{C}$ and at $0^{\circ} \mathrm{C}$ (living cells), and at $30^{\circ} \mathrm{C}$ (dead cells). The silicate accumulation in the cells is determined with the use of a

${ }^{31} \mathrm{Si}$-silicate tracer. All datapoints are averages $(n \geq 3, \pm \mathrm{SD})$
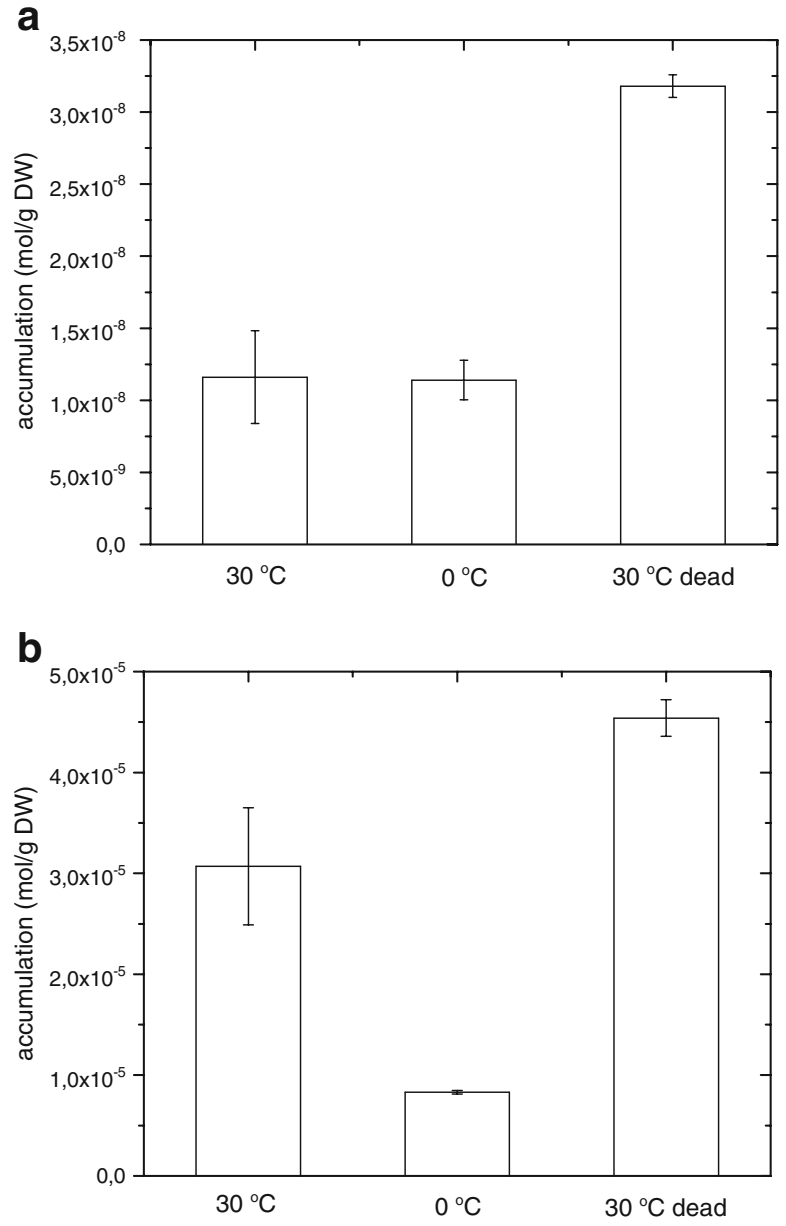

\section{Determination of Silicate Adsorption on the Cell Wall}

The above described results indicate that the interaction of silicate with the cell could take place by a chemical mechanism. Moreover, the silicate accumulation in dead cells indicates that the surface area of the cell possibly plays a role in the interaction of silicate with the cell. In this experiment, it is investigated whether silicate accumulation in the cell can be described by an adsorption mechanism. Yeast cells are incubated for $120 \mathrm{~min}$ at different silicate concentrations, and the silicate accumulation is determined (Fig. 4).

The silicate accumulation falls apart in two regimes. Under $2 \mathrm{mmol} / \mathrm{l}$ silicate (low $\mathrm{Si}$ ), the accumulation increases linear with the concentration, while above $2 \mathrm{mmol} / \mathrm{l}$ (high $\mathrm{Si}$ ), the accumulation increases dramatically. It is remarkable that the transition between the two regimes at $2 \mathrm{mmol} / \mathrm{l}$ silicate coincides with the concentration orthosilicate starts to polymerize [7]. This makes it plausible that a chemical mechanism plays a role in silicate accumulation. The linear response in low-Si media supports the assumption of an adsorption mechanism and makes a biological uptake mechanism unlikely. Subsequently it is investigated if the accumulation behavior can be described by an adsorption 
Fig. 4 Silicate accumulation in yeast cells at different silicate concentrations. Yeast is cultured in normal media for $2 \mathrm{~h}$ and the silicate accumulation in the cells is determined with the use of a

${ }^{31} \mathrm{Si}$-silicate tracer. All datapoints are averages $(n=3-5 \pm \mathrm{SD})$. Note that the silicate concentration is in $\mathrm{mol} / \mathrm{l}$ and the adsorption in $\mathrm{mol} / \mathrm{gDW}$. The lines represent the Freundlich adsorption isotherms for the concentration regimes $\mathrm{Si}<2 \mathrm{mmol} / \mathrm{l}$ and $\mathrm{Si}>2 \mathrm{mmol} / \mathrm{l}$

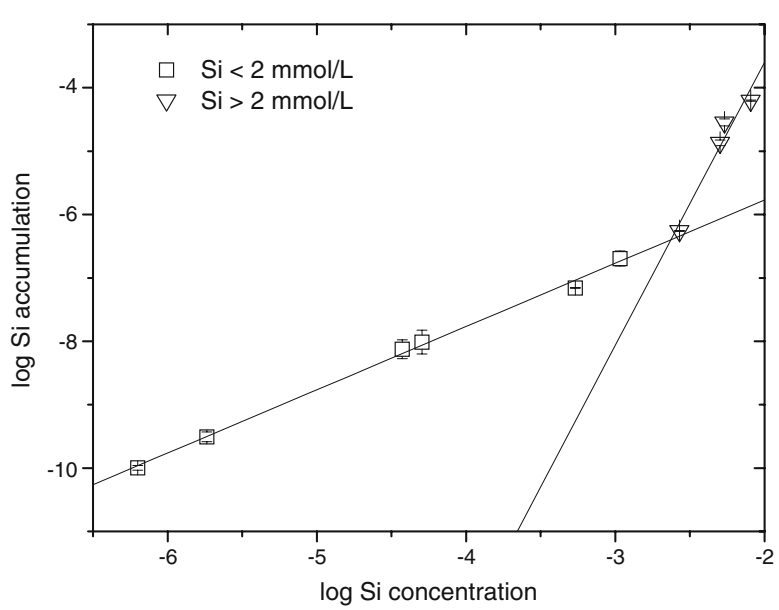

mechanism. A linear adsorption isotherm can be well described by a Freundlich isotherm (formula 1, "Materials and Methods"). The adsorption characteristics of the Freundlich adsorption are determined by the slope of the line $(1 / n)$ and the abscissa at $1 \mathrm{~mol} / \mathrm{l}\left(K_{\mathrm{ads}}\right)$. Both accumulation regimes in Fig. 4 are shown as Freundlich isotherms, and the parameters $1 / n$ and $K_{\text {ads }}$ are calculated and summarized in Table 1.

The two regimes have different adsorption characteristics as can be seen in Table 1. The value of $1 / n$ (order of the adsorption reaction) equals 1 in low-Si media, which means the adsorption is proportional to the silicate concentration. In high-Si media the value of $1 / n$ increases to 4. A remarkable increase of several orders of magnitude is observed for the affinity $K_{\text {ads }}$ in high-Si media. It is obvious the mechanisms differ in $\mathrm{Si}<2 \mathrm{mmol} / L$ and $\mathrm{Si}>2 \mathrm{mmol} / \mathrm{l}$.

The possibility of an adsorption mechanism is further investigated. Cells grown in high-Si media should contain a layer of silicate oligomers adsorbed to the cell's surface if adsorption takes place. When these cells are brought in no-Si added media the silicate layer on the cell wall should start to depolymerize. When the cells are grown in ${ }^{31} \mathrm{Si}$-containing media, this depolymerization process will be visible as a release of ${ }^{31} \mathrm{Si}$ from the cell biomass. Chemical depolymerization follows chemical pseudo second order kinetics [22, 24], so the release rate of ${ }^{31} \mathrm{Si}$ from the cell was calculated using chemical depolymerization kinetics.

Cells grown in $10 \mathrm{mmol} / \mathrm{l}$ silicate and ${ }^{31} \mathrm{Si}$ were put in no-Si added media and the silicate release was determined. The data were fitted to pseudo second order kinetics (formula 3, "Materials and Methods"), and the depolymerization rate constant $K_{d}$ was calculated and compared to the theoretical depolymerization rate constant under the given culture conditions. Figure 5 shows a typical example of silicate release from yeast cells. The silicate release results fitted well in pseudo second order kinetics, and yielded a rate constant of $22.0 \pm 9.3 \mathrm{l} /(\mathrm{mol} \cdot \mathrm{min}$ ) (weighted means, $n=3)$. This value is in agreement

Table 1 Values of Freundlich Adsorption Parameters, as Calculated from Silicate Accumulation in Yeast Cells at Different Silicate Concentrations

\begin{tabular}{lll}
\hline Regime & $1 / n(-)$ & $K_{\text {ads }}(\mathrm{mol} / \mathrm{gDW})$ \\
\hline $\mathrm{Si}<2 \mathrm{mmol} / 1$ & $1.01 \pm 0.03$ & $1.92 \pm 0.06 \cdot 10^{-4}$ \\
$\mathrm{Si}>2 \mathrm{mmol} / 1$ & $4.04 \pm 0.46$ & $2.70 \pm 0.63 \cdot 10^{4}$ \\
\hline
\end{tabular}


Fig. 5 Typical diagram of silicate release from a yeast cell suspension, $1 / C_{\text {cell }}$ is shown against time. The cells were cultured for $4 \mathrm{~h}$ in $10 \mathrm{mmol} / \mathrm{l} \mathrm{Si}$ in the presence of a ${ }^{31} \mathrm{Si}$-silicate tracer, harvested, and put in no Si-added medium. At different time intervals samples were taken and the silicate concentration in the supernatant of the medium $C_{\text {med }}$ was determined to calculate $C_{\text {cell. }}$. The slope yields the depolymerization rate constant of polysilicate adsorbed on the cell wall (see "Materials and Methods")

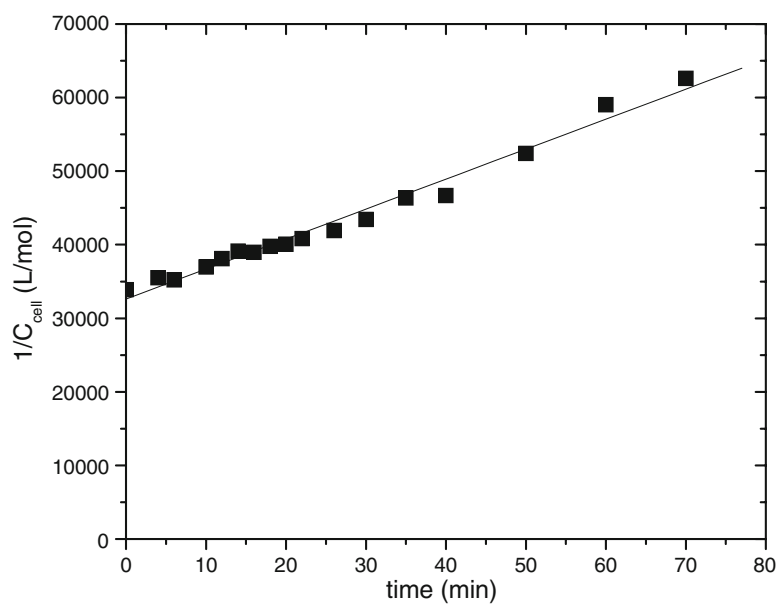

$(P=0.48)$ with the theoretical $K_{d}$ value of $25.2 \mathrm{l} /(\mathrm{mol} \cdot \mathrm{min})$ belonging to standard medium. From the results, it can be concluded that pseudo second order depolymerization kinetics can be applied for silicate release from yeast cells. These findings confirm silicate adsorption on the cell surface.

\section{Interaction of Metal Ions with Adsorbed Silicate}

Earlier it was found silicate interacts with several metals in the yeast cell [26]. In this experiment, it is investigated whether interaction of metals can be observed with the adsorbed silicate op the cell wall. The influence of the medium components zinc and magnesium on the Freundlich parameters $1 / n$ and $K_{\text {ads }}$ of silicate adsorption was determined. Both zinc and magnesium are able to form a complex with silicate, and zinc has a profound influence on silicate polymerization [7, 20-24]. So it can be expected that both zinc and magnesium will influence the affinity $K_{\text {ads }}$, and that zinc will influence the order of the adsorption reaction $1 / n$ in high-Si media. The following media are investigated: $0.03 \mu \mathrm{mol} / 1$, or $0.1 \mathrm{mmol} / 1 \mathrm{Zn}^{2+}\left(\mathrm{Mg}^{2+}\right.$ as in standard media) and $0.54 \mathrm{mmol} / 1 \mathrm{Mg}^{2+}\left(\mathrm{Zn}^{2+}\right.$ as in standard media), and the results are added to the above-described experiment in standard media $\left(16 \mu \mathrm{mol} / 1 \mathrm{Zn}^{2+}, 4.2 \mathrm{mmol} / \mathrm{l} \mathrm{Mg}^{2+}\right)$. The cultures were inoculated from a $1 \mu \mathrm{mol} / 1$ silicate (= no-Si added) preculture, the silicate accumulation was determined at different silicate concentrations, and the Freundlich parameters $1 / n$ (slope) and $K_{\text {ads }}$ (abscissa at $1 \mathrm{~mol} / 1 \mathrm{Si}$ ) were calculated from the results and summarized in Figs. 6 and 7.

In $0.03 \mu \mathrm{mol} / 1 \mathrm{Zn}^{2+}$ (high-Si media) the amount or size of oligomers was clearly increased and caused clogging of the filter. For this reason, the sample volume was lowered from 10 to $1 \mathrm{ml}$. Figure 5 shows that $1 / n$ is not affected by the $\mathrm{Zn}^{2+}$ or $\mathrm{Mg}^{2+}$ concentration in low-Si medium, and has the value 1 . This means that the adsorption of silicate is a first order process, which is not influenced by $\mathrm{Zn}^{2+}$ or $\mathrm{Mg}^{2+}$ ions. In high-Si media, the value of $1 / n$ increases to $3.5-5.2$ and is affected by the $\mathrm{Zn}^{2+}$ concentration but not by the $\mathrm{Mg}^{2+}$ concentration.

The affinity $K_{\text {ads }}$ (Fig. 6) is influenced by the $\mathrm{Zn}^{2+}$ and $\mathrm{Mg}^{2+}$ concentration. In low-Si media, $K_{\text {ads }}$ increases with increasing $\mathrm{Zn}^{2+}$ or $\mathrm{Mg}^{2+}$ concentration. In high-Si media, $K_{\text {ads }}$ decreases dramatically with increasing $\mathrm{Zn}^{2+}$ concentration but increases with increasing $\mathrm{Mg}^{2+}$ concentration. 
Fig. 6 Freundlich adsorption parameter $1 / n$ for silicate adsorption on Baker's yeast. a Dependency of $\mathrm{Zn}^{2+}$ concentration, and b dependency of the $\mathrm{Mg}^{2+}$ concentration. Yeast was cultured for $2 \mathrm{~h}$ at different silicate concentrations and the silicate accumulation in the cells was determined with use of a ${ }^{31} \mathrm{Si}-$ silicate tracer. From the results, the freundlich parameter $1 / n$ is determined
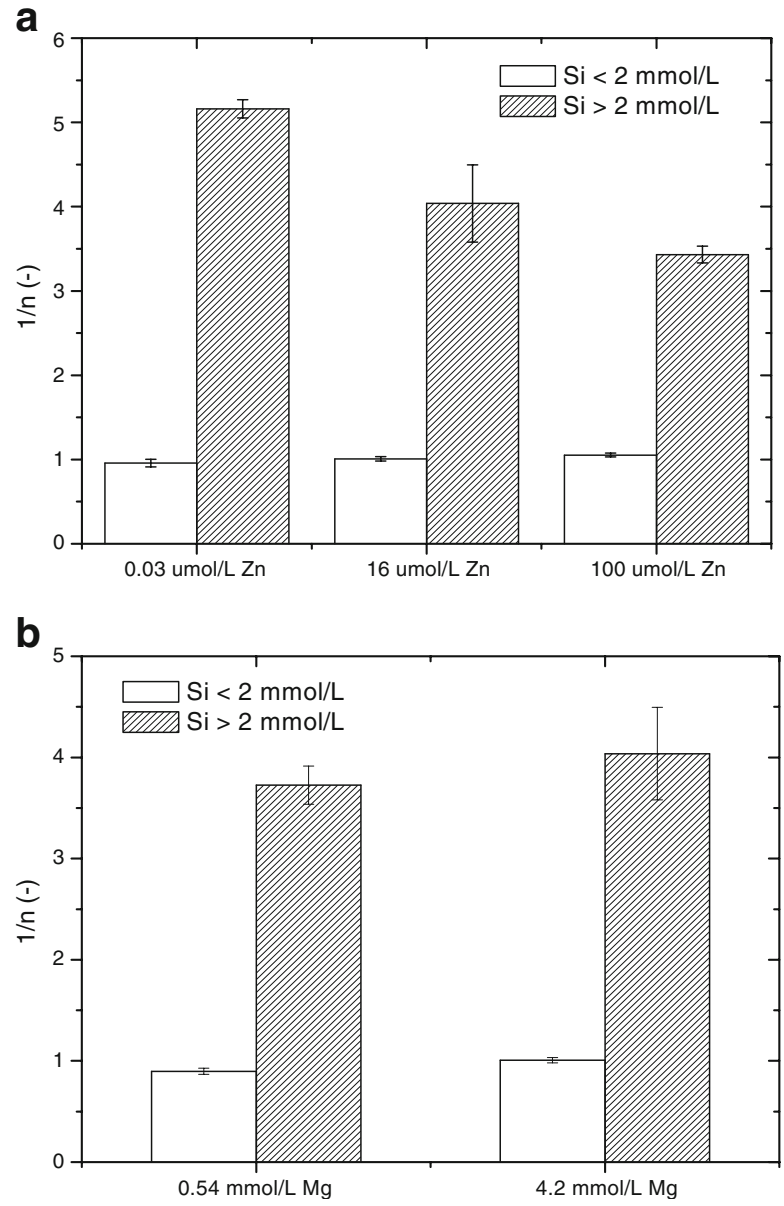

\section{Discussion}

Silicate is accumulated by living cells at $30^{\circ} \mathrm{C}$ as well as at $0^{\circ} \mathrm{C}$ and by dead cells $\left(30^{\circ} \mathrm{C}\right.$; Figs. 1 and 3). At $0^{\circ} \mathrm{C}$, the accumulation is reduced in high-Si media. The temperature affects the polymerization rate and the size of silicate oligomers [7, 30]. The decreased polymerization rate results in smaller oligomers, so accumulation of the same amount of molecules will result in a lower observed ${ }^{31} \mathrm{Si}$ accumulation. The activation energy of silicate polymerization is $60 \mathrm{~kJ} / \mathrm{mol}$ [30]. It can be calculated that the polymerization rate of silicate decreases with $90 \%$ when the temperature is lowered from 30 to $0^{\circ} \mathrm{C}$, which is in good agreement with the observed decrease in accumulation. The increased accumulation in dead cells can be explained by the increased surface area of the cells. Probably the swelling of the cells makes it possible more adsorption sites can be reached by the silicate molecules in the solution. Furthermore, it is feasible that the dead cell's membrane becomes permeable allowing orthosilicate and (to a lesser extend) silicate oligomers to diffuse into the cell.

The silicate accumulation in yeast shows a linear dependency of the silicate concentration up to $2 \mathrm{mmol} / \mathrm{l}$. Above this concentration, the accumulation shows a 
Fig. 7 Freundlich adsorption parameter $K_{\text {ads }}$ for silicate adsorption on Baker's yeast. a Dependency of $\mathrm{Zn}^{2+}$ concentration, and $\mathbf{b}$ dependency of $\mathrm{Mg}^{2+}$ concentration. Note that in a $K_{\text {ads }}$ for $[\mathrm{Si}]>2 \mathrm{mmol} / L$ is displayed on a logarithmic scale. Yeast is cultured for $2 \mathrm{~h}$ at different silicate concentrations and the silicate accumulation in the cells is determined with use of ${ }^{31} \mathrm{Si}-$ silicate tracer. From the results, the freundlich parameter $K_{\mathrm{ads}}$ is determined
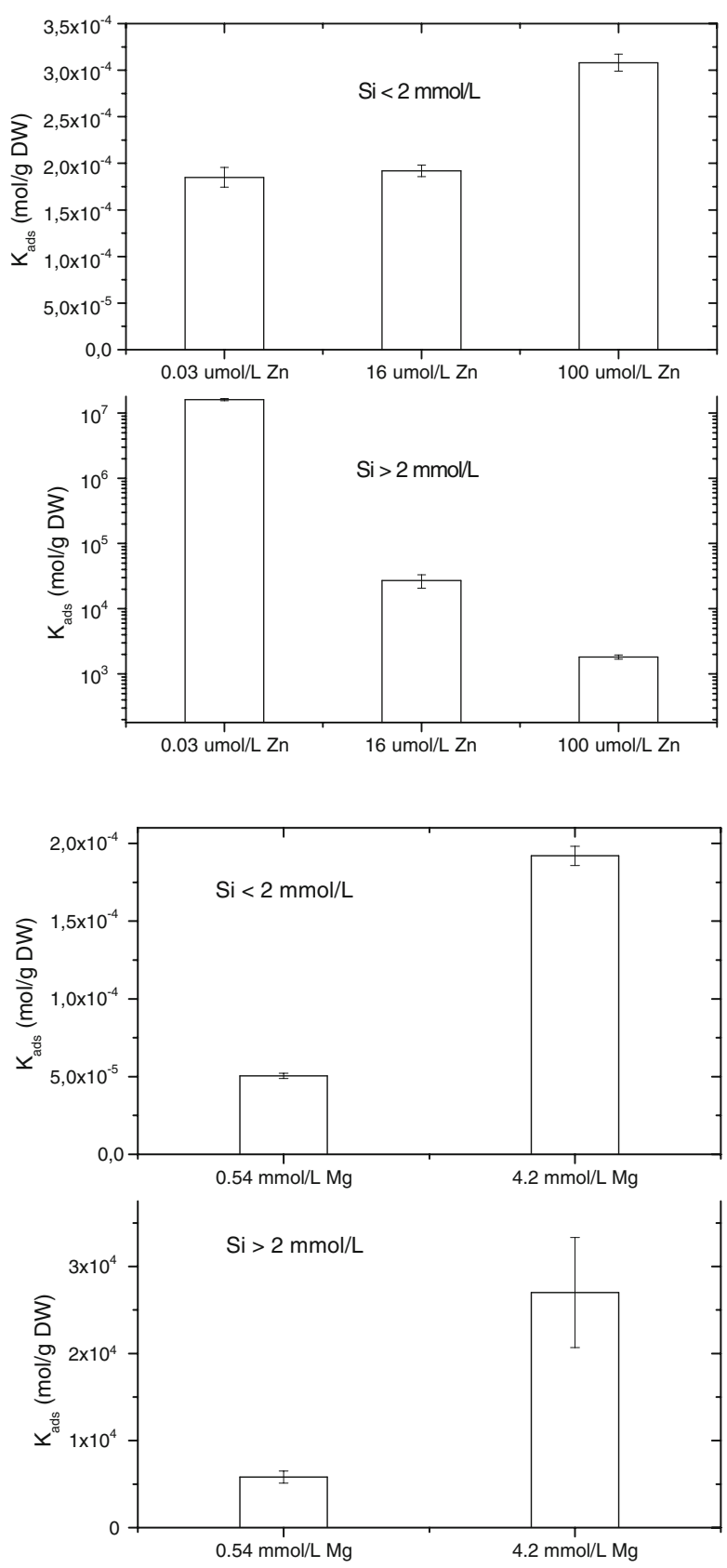

dramatic increase (Fig. 4). These two regimes correspond with the two regimes in silicate chemistry: $<2 \mathrm{mmol} / 1$ (low $\mathrm{Si}$, silicate exists as orthosilicate), and $>2 \mathrm{mmol} / \mathrm{l}$ (high $\mathrm{Si}$, silicate starts to polymerize) [7]. The silicate accumulation in both regimes can be described by an adsorption mechanism, and the Freundlich isotherm fits well for this purpose. The linear response makes a biological uptake mechanism unlikely. The release of silicate from 
the cell wall follows silicate depolymerization kinetics and supports the assumption of silicate adsorption on the cell wall.

The two concentration regimes have different adsorption characteristics as can be seen in Table 1 and Figs. 6 and 7. In low Si, the value of $1 / n$ equals 1 , regardless of $\mathrm{Zn}^{2+}$ and $\mathrm{Mg}^{2+}$ in the medium, but it increases to 3.5-5.2 in high Si. It is striking the value of $1 / n$ (order of the adsorption reaction) equals 1 in low $\mathrm{Si}$. This means that the adsorption is proportional to the silicate concentration as a first order process (one silicate molecule per adsorption site). In high-Si media, the order of the adsorption reaction $1 / n$ increases to 3.5-5.2, which means 3 to 5 silicate molecules per adsorption site. Since $1 / n$ reflects the order of the adsorption process [29], it is likely $1 / n$ shows the degree of polymerization. Note that the silicate concentration in the experiments is expressed in millimoles monosilicate, the degree of polymerization is not taken into account.

$\mathrm{Zn}^{2+}$ and $\mathrm{Mg}^{2+}$ influence the adsorption process (Figs. 6 and 7). In $0.03 \mu \mathrm{mol} / \mathrm{Z} \mathrm{Zn}^{2+}$ (high $\mathrm{Si}$ ) media, the degree of polymerization of silicate was higher than in other media, which was clearly visible during the experiment (clogging of the filter). A high value of $1 / n$ (5.2) was obtained under these circumstances. $\mathrm{Zn}^{2+}$ ions are known to influence the (de) polymerization of silicate $[22,24] . \mathrm{Mg}^{2+}$ does not affect the polymerization of silicate, and this explains why $1 / n$ remains constant at different $\mathrm{Mg}^{2+}$ concentrations.

The adsorption affinity $K_{\text {ads }}$ differ orders of magnitude in low-Si and high-Si media, which is a clear indication two chemically entirely different processes take place. Obviously, the existence of silicate oligomers in high Si results in a much higher silicate adsorption on the cell wall. $K_{\text {ads }}$ increases with the $\mathrm{Zn}^{2+}$ and $\mathrm{Mg}^{2+}$ concentration, except for $\mathrm{Zn}^{2+}$ in high-Si media. Low $\mathrm{Zn}^{2+}$ strongly enhances $K_{\text {ads }}$ in high-Si media, which can be explained by the increased polymerization of silicate under these conditions (Fig. 6). The increase of $K_{\text {ads }}$ by $\mathrm{Mg}^{2+}$ (low and high $\mathrm{Si}$ ) and by $\mathrm{Zn}^{2+}$ (low $\mathrm{Si}$ ) could be explained by the formation of stable metal-monosilicates (low $\mathrm{Si}$ ) or Mg-silicate complexes (high $\mathrm{Si}$ ). The $\mathrm{Zn}$-silicate complex in high $\mathrm{Si}$ is unstable, and this could also explain the decrease in $K_{\text {ads }}$ with increasing $\mathrm{Zn}$. More research is needed on this.

It can be concluded that the adsorbed layer of silicate on the cell wall can interact with metal ions, and in doing so can play a role in the interaction of metal ions with the cell itself. Probably the adsorbed silicate has an influence on the cell's affinity for metal ions which is entirely dependant of chemistry. The results of earlier work [26] can be explained by this. The formation of a stable $\mathrm{Mg}$-silicate complex on the cell wall could cause $\mathrm{Mg}^{2+}$ ions to be "trapped" on the cell wall, reducing the availability of $\mathrm{Mg}^{2+}$ ions for the cell. The increased adsorption of silicate oligomers (in low $\mathrm{Zn}$ ) and the instability of the $\mathrm{Zn}$-silicate complex on the other hand could help the cell "harvesting" $\mathrm{Zn}^{2+}$ ions that are easily released again near to the cell membrane. This could cause an increased availability of $\mathrm{Zn}^{2+}$. The observed effects in this study could be explained by this. The adsorbed silicate can also shield several compounds in the cell wall itself.

From the above, it is expected that silicate can interfere with biological processes by adsorption to yeast cells and subsequent chemical interaction with metal ions. Most likely, similar consequences of Si chemistry can also occur in other organisms than yeast. In Bacillus subtilis for example, silicate precipitation on the cell wall was observed previously [31]. And although animal cells do not possess a cell wall in general, the animal cell membrane contains many glycolipids and glycoproteins [32] that could serve as an adsorption site for silicate molecules. Since complex formation between silicate oligomers and several saccharides can occur [33-35], it is likely that silicate can adsorb on the animal cell membrane as well. In higher animals and humans silicate affects metal concentrations in many tissues and several enzymatic activities. Presumably, silicate interacts with metal 
ions in the tissues in a chemical way and hence affects the availability of the metals. Therefore, silicon chemistry should be incorporated carefully in future hypotheses and investigations on the roles of silicon in living organisms including humans.

Acknowledgement The authors wish to acknowledge Ehsan Marandi and Jorrit Heikamp for experimental help and Tona Verburg for useful advises on statistics and modeling.

\section{References}

1. Lide LR (ed) (2002) CRC Handbook of Chemistry and Physics, 83rd edn. CRC Press LLC, Boca Raton Florida

2. Aston S (ed) (1983) Silicon geochemistry and biogeochemistry. Academic, London

3. Tréguer P, Nelson DM, van Bennekom AJ, DeMaster DJ, Leynaert A, Quéguiner B (1995) The silica balance in the world ocean-a reestimate. Science 268:375-379 DOI 10.1126/science.268.5209.375

4. Conley DJ (1997) Riverine contribution of biogenic silica to the ocean budget. Limnol Oceanogr 42:774-777

5. Willén E (1991) Planctonic diatoms-An ecological review. Arch Hydrobiol 69(suppl. 89):69-106

6. Petzold A, Hinz W (1978) Silikatchemie, Einführung in die Grundlagen. VEB Deutsche Verlag für Grundstoffindustrie, Leipzig (in German)

7. Iler RK (1979) The chemistry of silica. John Wiley \& Sons, New York

8. Smith JV, Arnold FP, Parsons I, Lee MR (1999) Biochemical evolution III: Polymerization on organophilic silica-rich surfaces, crystal-chemical modeling, formation of first cells, and geological clues. Proc Natl Acad Sci USA 96:3479-3485

9. Epstein E (1999) Silicon. Annu Rev Plant Physiol 50:641-664 DOI 10.1146/annurev.arplant.50.1.641

10. Neumann D, zur Nieden U (2001) Silicon and heavy metal tolerance in higher plants. Phytochemistry 56:685-692 DOI 10.1016/S0031-9422(00)00472-6

11. Neumann D, de Figueiredo C (2002) A novel mechanism of silicon uptake. Protoplasma 220:59-67 DOI $10.1007 / \mathrm{s} 00709-002-0034-7$

12. Evered D, O’Connor M (eds) (1986) Silicon biochemistry. Wiley, Chechester

13. Simpson TL, Volcani BE (1981) Silicon and siliceous structures in biological systems. Springer Verlag, New York

14. Birchall JD (1990) Chem Brit 26:141-144

15. Seaborn CD, Nielsen FH (2002) Silicon deprivation and arginine and cysteine supplementation affect bone collagen and bone and plasma trace mineral concentrations in rats. J Trac Elem Exp Med 15:113122 DOI 10.1002/jtra.10011

16. Valerio P, Pereira MM, Goes AM, Leite MF (2004) The effect of ionic products from bioactive glass dissolution on osteoblasts proliferation and collagen production. Biomaterials 25:2941-2948 DOI 10.1016/j.biomaterials.2003.09.086

17. Martin-Jezequel V, Hildebrand M, Brzezinski MA (2000) Silicon metabolism in diatoms: implications for growth. J Phycol 36:821-840 DOI 10.1046/j.1529-8817.2000.00019.x

18. Müller WEG, Krasko A, Le Pennec G, Schröder HC (2003) Biochemistry and cell biology of silica formation in sponges. Microscop Res Tech 62:368-377 DOI 10.1002/jemt.10402

19. Exley C (1998) Silicon in life: A bioinorganic solution to bioorganic essentiality. J Inorg Biochem 69:139-144

20. Schwieger W, Heyer W, Wolf F, Berg KH (1987) Zur Synthese von kristallinen Metallsilicathydraten mit Schichtstruktur. Z Anorg Chem 548:204-216 (in German)

21. Marshall WL, Warakomski JM (1980) Amorphous silica solubilities-II. Effect of aqueous salt solutions. Geochim Cosmochim Acta 44:915-924

22. Dietzel M, Usdowski E (1995) Depolymerization of soluble silicate in dilute aqueous solutions. Colloid Polym Sci 273:590-597 DOI 10.1007/BF00658690

23. Dietzel M, Böhme G (1997) Adsorption und Stabilität von polymerer Kieselsäure. Chem Erde-Geochem 57:189-203 (in German)

24. Dietzel M (2000) Dissolution of silicates and the stability of polysilicic acid. Geochim Cosmochim Acta 64:3275-3281 DOI 10.1016/S0016-7037(00)00426-9

25. Walker GM (1998) Yeast physiology and biotechnology. Wiley, Chichester

26. Brasser HJ, Krijger GC, van Meerten TG, Wolterbeek HT (2006) Influence of silicon on cobalt, zinc, and magnesium in Baker's yeast Saccharomyces cerevisiae. Biol Trace Elem Res 112:175-190 
27. Brasser HJ, Gürboğa G, Kroon JJ, Kolar ZI, Wolterbeek HT, Volkers KJ, Krijger GC (2006) Preparation of ${ }^{31}$ Si-labeled silicate: a radiotracer for silicon studies in biosystems. J Labelled Compd Radiopharm 47:867-882 DOI 10.1002/jlcr.1096

28. Verduyn C, Postma E, Scheffers A, van Dijken JP (1992) Effect of benzoic acid on the metabolic fluxes in yeast: a continuous-culture study on the regulation of respiration and alcoholic fermentation. Yeast 8:501-517

29. Adamson AW, Gast AP (1997) Physical chemistry of surfaces, 6th edn. John Wiley \& Sons, Inc., New York

30. Coudurier M, Baudru B, Donnet JB (1971) Étude de la polycondensation de l'acide disilicique. III.Influence de la concentration et de la température sur la cinétique et le mécanisme de la polycondensation de l'acide disilicique. Relation avec la texture des produits formés. Bull Soc Chim France 9:3161-3165 (in French)

31. Fein JB, Scott S, Rivera N (2002) The effect of Fe on Si adsorption by Bacillus subtilis cell walls:insight into non-metabolic bacterial precipitation of silicate minerals. Chem Geol 182:265-273

32. Stryer L (1981) Biochemistry. W.H. Freeman and Company, San Francisco

33. Kinrade SD, Hamilton RJ, Schach AS, Knight CTG (2001) Aqueous hypervalent silicon complexes with aliphatic sugar acids. J Chem Soc Dalt T 7:961-963

34. Kinrade SD, Del Nin JW, Schach AS, Sloan TA, Wilson KL, Knight CTG (1999) Stable five- and sixcoordinated silicate anions in aqueous solution. Science 285:1542-1545

35. Lambert JB, Lu G, Singer SR, Kolb VM (2004) Silicate complexes of sugars in aqueous solution. J Am Chem Soc 126:9611-9625 